\title{
METHANE EMISSION FACTORS FROM INDIGENOUS CATTLE BREED IN SMALLHOLDER LIVESTOCK PRODUCTION SYSTEMS IN ETHIOPIA
}

\author{
Million TDESSE and Kefale GETAHUN ${ }^{\star 凶}$ \\ Ethiopian Institute of Agricultural Research, Holetta Agricultural Research Center, P. O. Box 2003 Addis Ababa or 31 Holetta, Ethiopia \\ Email: kefalegetahun@gmail.com; (D) ORCiD: 0000-0003-1937-4793 \\ Supporting Information
}

\begin{abstract}
The objective of this study was to estimate methane $(\mathrm{CH} 4)$ emission factor from enteric fermentation and manure management in indigenous cattle in Ethiopian highland using intergovernmental panel on climate change (IPCC) tier 2 methodologies. A survey was conducted in 2018 using questionnaire regarding cattle management, feed and feeding system on 50 smallholder farmers in central Ethiopia. Information was also collected from literature and contact with federal and regional research institutions. This information was used as input in the IPCC tier 2 methodologies for estimation of $\mathrm{CH} 4$ emission factors for eight cattle sub-categories. Results indicated that enteric $\mathrm{CH} 4$ emission factors were estimated to be 65 , 49, 37, 56, 66, 58, 63 and 11 for mature lactating cows, dry cows, heifers (2-3 years), growing females (1-2 years), draught oxen, mature breeding males, growing males (1-2 years) and calves $(<1$ year), respectively. Manure management $\mathrm{CH} 4$ emission factors were 4.97, 3.77, 2.86, 4.33, 5.06, 4.47, 4.88 and 1.71 $\mathrm{kg} / \mathrm{head} /$ year for mature lactating cows, dry cows, heifers (2-3 years), growing females (1-2 years), draught oxen, mature breeding males, growing males (1-2 years) and calves $(<1$ year), respectively. The present estimate on enteric $\mathrm{CH} 4$ emission factor using tier 2 methodologies in present study ranged from 11 to $66 \mathrm{~kg}$ per head per year while manure management $\mathrm{CH} 4$ emission factor ranged from 1.71 to $5 \mathrm{~kg}$ per head per year. These values are higher than the IPCC 2006 tier 1 default values for African region. However, present work's estimates are within a range of literature reports for other cattle in different countries. Further research is required to improve emission factors estimates using primary data on live weight, animal performance and feed characterization.
\end{abstract}

Keywords: Emission, Greenhouse gas, Livestock, Manure, Methane.

Abbreviations: $\mathrm{CH} 4$; methane, DE; digestible energy, GDP; gross domestic product, GE; gross energy, GHG; greenhouse gas, $\mathrm{EF}$; emission factor, IPCC; intergovernmental panel on climate change, MCF; methane conversion factor, MCV; default methane conversion value, MJ; mega joule, MS; manure management system, UE; urinary energy, VS; volatile solid.

\section{INTRODUCTION}

The agricultural sector contributes more than 45 percent to the Ethiopian gross domestic product (GDP) (Ayele et al., 2003). Livestock sub-sector creates livelihood for $65 \%$ of the rural population and accounts for about $12-15 \%$ of the national export earnings (Ayele et al., 2003). Livestock in Ethiopia are essential source of protein and nutrition to human diet through milk, eggs, meat and used as a source of financial services and way of spreading risk (Sheehy et al., 2019; Haileselassie et al., 2020).

However, the livestock production system in Ethiopia contributes to global climate change directly through production of $\mathrm{CH} 4$ from enteric fermentation and manure management (Berhanu et al., 2019). So far, national GHG emission inventories from livestock in the country are calculated using the International Panel on Climatic Change (IPCC, 2006) Tier-1 approach. This methodology calculates $\mathrm{CH} 4$ emissions for each animal category by multiplying the animal population number by default emissions factor for the specific animal category (IPCC, 2006). Based on these estimates cattle accounts for $90 \%$ of total livestock enteric CH4 emissions (CRGE, 2011). The use of IPCC Tier 1 default emission factors which are available for Africa may not represent the Ethiopian situation because emission factors vary within each region/country depending on livestock breed, production parameters and feed characteristics (IPCC, 2006).

The objective of this study was to determine enteric fermentation and manure management $\mathrm{CH} 4$ emission factors from indigenous cattle breed in Ethiopian highland.

\section{MATERIALS AND METHODS}

\section{Ethical approval}

No explanation of experimental ethics is needed as this study was done by using retrospective data and baseline survey. The authors acknowledged and properly cited the scholars work. 


\section{Research approach}

Questionnaire based survey was conducted during 2018 using about 50 smallholder farmers to collected data on production performance, manure management and feed types that required for estimation of tier $2 \mathrm{CH} 4$ emission factor. Moreover, information was also collected from personal communication (researcher at federal and regional research institutions), as well as from district level development workers. Information on average body weight, mature weight, average daily growth rate, average daily milk yield, milk fat content, type of production environment, pregnancy rates, type and quality of feed provided for each animal sub-category were collected through survey and literature review.

Average number of hours spent for traction was estimated from survey data on number of hour's oxen spent on cultivation and threshing. The average working time spent for cultivation by mature males per day was estimated to be 7 hours for average of 60 days per year while the average working time spent for thrashing crop harvest was 7.04 hours per day and for $\mathbf{3 0}$ days per year. The weighted average hours spent for cultivation of crop land and for thrashing of crop harvest per animal was 1.15 and 0.57 hours per day respectively.

Table 1 indicated proportion of each feed type to total diet, digestible energy (DE \%) of each feed type and weighted average value of $\mathrm{DE} \%$, of feed types. Average DE\% was estimated from data collected during survey work on feed types farmer provided to each animal. DE\% of each feed type was obtained from literature (Seyoum et al., 2007). Data that was not obtained from survey work for example live weight for each sub-category (Table 2), average growth rate for young animals and average daily milk yield (Table 3 ) for lactating cows, percentage of fat in milk (4\%) and calving rate of cows (CSA, 2017) were obtained from literature report.

\section{Table 1 - Feed types used for cattle and feed \%DE estimates}

\begin{tabular}{lccc} 
Feed types & Proportion to total feed & DE\% & Weight DE\% \\
\hline Natural grazing & $44 \%$ & $49 \%$ & $21.56 \%$ \\
Crop residue & $33 \%$ & $49 \%$ & $16.17 \%$ \\
Green feed (grass and legumes) & $12 \%$ & $61 \%$ & $7.32 \%$ \\
Grass hay & $11 \%$ & $47 \%$ & $5.17 \%$ \\
Weighted average & & $50.22 \%$ \\
\hline *Source: Seyoum et al. (2007). & & \\
\hline
\end{tabular}

Table 2 - Average live weight of cattle breeds

\begin{tabular}{|c|c|c|c|c|c|c|c|c|}
\hline \multirow[b]{2}{*}{ Breed } & \multirow[b]{2}{*}{$\begin{array}{c}\text { Calves }<1 \\
\text { years }\end{array}$} & \multicolumn{3}{|c|}{ Male } & \multicolumn{3}{|c|}{ Females } & \multirow[b]{2}{*}{ Reference } \\
\hline & & $\begin{array}{c}\text { Growing } \\
\text { males (1-2 } \\
\text { years) }\end{array}$ & $\begin{array}{l}\text { Breeding } \\
\text { bulls }\end{array}$ & $\begin{array}{c}\text { Mature } \\
\text { males }>\mathbf{3} \\
\text { years }\end{array}$ & $\begin{array}{c}\text { Growing } \\
\text { females } \\
\text { (1-2 years) }\end{array}$ & $\begin{array}{l}\text { Heifers } \\
(2-3 \\
\text { years) }\end{array}$ & $\begin{array}{c}\text { Mature lactating } \\
\text { and dry cows }>3 \\
\text { years }\end{array}$ & \\
\hline Barca & & 182.85 & 257.54 & 326 & 134 & 188.81 & 239 & $\begin{array}{l}\text { Haile-Mariam (1994); } \\
\text { DAGRIS (2007) }\end{array}$ \\
\hline Horro & & 112 & 267 & 382 & 115 & 160 & 256 & $\begin{array}{l}\text { Demeke et al. (2003; 2004); } \\
\text { Abera et al. (2012) }\end{array}$ \\
\hline Horro & & & & & & & 247 & Abera et al. (2012) \\
\hline Boran & & 192 & 269 & 342.5 & & & 285 & Haile-Mariam (1994) \\
\hline Ogaden & & & & 285.7 & 126.75 & 178 & & $\begin{array}{l}\text { Moges and Baars (1998), } \\
\text { Ermias (2001) }\end{array}$ \\
\hline Afar & & & & 312.5 & & & 245 & Epsten (1971) \\
\hline Fogera & & & & & & & 256 & DAGRIS (2007) \\
\hline Zebu & 57 & & & & & & & Shapiro et al. (2017) \\
\hline Average & 57 & 162.28 & 264.51 & 333.95 & 125.25 & 175.60 & 254.67 & \\
\hline
\end{tabular}

\section{Table 3 - Average daily growth rate and milk yield cattle (head/day)}

\begin{tabular}{lcccc} 
Parameters & Borena & Begait & Horro & Fogera \\
\hline Average daily growth, gram/day & 401.40 & 385.30 & 377.60 & - \\
Daily milk yield, liters per day per animal & 1.70 & - & - & 2.32 \\
\hline *Source: Demeke et al. (2003; 2004); Mekonnen (1983); Kiwuwa et al. (1983); Trail and Gregory (1981). & & \\
\hline
\end{tabular}

\section{Method used for estimation of enteric $\mathrm{CH} 4$ emission factor}

CH4 emission factors from enteric fermentation in cattle were calculated for 8 cattle species sub-categories using gross energy intake (GE) and methane conversion factor (Ym) as input in the following (IPCC, 2006) equation: 
$E F=\left[\frac{G E \cdot\left(\frac{Y_{m}}{100}\right) \cdot 365}{55.65}\right]$

Where;

$\mathrm{EF}=$ Methane emission factor from enteric fermentation, $\mathrm{kg} \mathrm{CH} 4 /$ animal/year

$\mathrm{GE}=$ Gross energy intake, MJ/animal/day

$\mathrm{Ym}=$ Methane conversion factor, percent of gross energy in feed converted to $\mathrm{CH} 4$

The factor 55.65 (MJ/kg methane) is the energy content of methane

Average GE intake was calculated using net energy requirement for body maintenance, activity, work, lactation (lactating cows), pregnancy and net energy for growth (young animals). These net energies were estimated using IPCC (2006) tier 2 methods.

\section{Methods for estimation of $\mathrm{CH} 4$ emission factor for manure managements}

Manure management emissions from livestock was arise from the anaerobic decomposition of organic material in the manure in the report of IPCC (2006). These conditions occur mostly when large numbers of animals are managed in a confined area, and where manure is disposed of in liquid-based systems. In this study, it was identified about 6 manure management practices in smallholder production system in central highland during survey work. The majority of manure produced is handled as pasture/range, liquid system, solid system, dry lot, daily spread and burn for fuel (Table 4).

Manure characteristics such as volatile solids (VS) content of manure, the maximum amount of methane able to be produced from that manure (Bo) and a system-specific methane conversion factor (MCF) were used to estimate manure management $\mathrm{CH} 4$ emission factor using IPCC tier 2 methodology. The description of manure management systems are indicated in Table 4. No country specific data were identified for Bo or MCF. For Bo, the IPCC default value of 0.1 for other cattle was used (IPCC, 2006). For MCF values, the IPCC default values (IPCC, 2006) were used Table 2, assuming a tropical montane climate for mixed crop-livestock systems. Weighted average MCF was developed using the estimates of the manure managed by each waste system and default MCV. The weighted average MCF was then multiplied by the value of VS excretion rate and IPCC default Bo for each sub-category (IPCC, 2006). In equation form, the estimate is as follows:

$$
\mathrm{EFt}=(\mathrm{VSt} * 365) *\left[\mathrm{Bo}(\mathrm{t}) * 0.67 \frac{\mathrm{kg}}{\mathrm{m} 3} * \frac{\sum \mathrm{MCF}(\mathrm{s}, \mathrm{k})}{100} * \mathrm{MS}(\mathrm{t}, \mathrm{s}, \mathrm{k})\right\}
$$

$\mathrm{EF}(\mathrm{t})=\mathrm{CH} 4$ emission factor per year from manure management for cattle sub-category $\mathrm{t}, \mathrm{kg} \mathrm{CH} 4 /$ anima/head/year

VS $(t)=$ daily volatile solid excreted for cattle sub-category $\mathrm{t}, \mathrm{kg}$ dry matter/ head/day

365 days = is basis for estimating annual VS production, days/year

$\mathrm{Bo}(\mathrm{t})=$ maximum methane producing capacity for manure produced by cattle sub-category $\mathrm{t}, \mathrm{m} 3 \mathrm{CH} 4 / \mathrm{kg}$ of $\mathrm{VS}$ excreted

0.67 = conversion factor of $\mathrm{m}^{3} \mathrm{CH} 4$ to kilograms $\mathrm{CH} 4$

$\operatorname{MCF}(s, k)=$ methane conversion factors for each manure management system s by climate region $\mathrm{k}, \%$

$\mathrm{MS}(\mathrm{t}, \mathrm{s}, \mathrm{k})=$ fraction of cattle sub-category t's manure handled using manure management system $\mathrm{s}$ in climate region $k$, dimensionless

Table 4 - Input data on MMS, fraction of manure managed in MMS and manure management $\mathrm{CH} 4$ conversion factors

\begin{tabular}{l|l|c|c|c|c|c|c|c|c|c|c|c|}
\hline & \multicolumn{2}{|c|}{ Liquid system } & \multicolumn{2}{|c|}{ Solid storage } & \multicolumn{2}{|c|}{ Dry lot } & \multicolumn{2}{c|}{ Pasture (range) } & \multicolumn{2}{c|}{ Daily spread } & \multicolumn{2}{c|}{ Burn for fuel } \\
\cline { 2 - 11 } & $\begin{array}{c}\text { MS, } \\
\%\end{array}$ & $\begin{array}{c}\text { MCF, } \\
\%\end{array}$ & $\begin{array}{c}\text { MS, } \\
\%\end{array}$ & $\begin{array}{c}\text { MCF, } \\
\%\end{array}$ & $\begin{array}{c}\text { MS, } \\
\%\end{array}$ & $\begin{array}{c}\text { MCF, } \\
\%\end{array}$ & $\begin{array}{c}\text { MS, } \\
\%\end{array}$ & $\begin{array}{c}\text { MCF, } \\
\%\end{array}$ & $\begin{array}{c}\text { MS, } \\
\%\end{array}$ & $\begin{array}{c}\text { MCF, } \\
\%\end{array}$ & $\begin{array}{c}\text { MS, } \\
\%\end{array}$ & $\begin{array}{c}\text { MCF, } \\
\%\end{array}$ \\
\hline Lactating cows & 0.05 & 27.18 & 0.1 & 4 & 0.13 & 1.50 & 0.4 & 1.50 & 0.07 & 0.50 & 0.24 & 10 \\
Dry cows & 0.05 & 27.18 & 0.1 & 4 & 0.13 & 1.50 & 0.4 & 1.50 & 0.07 & 0.50 & 0.24 & 10 \\
Heifers & 0.05 & 27.18 & 0.1 & 4 & 0.13 & 1.50 & 0.4 & 1.50 & 0.07 & 0.50 & 0.24 & 10 \\
growing Female & 0.05 & 27.18 & 0.1 & 4 & 0.13 & 1.50 & 0.4 & 1.50 & 0.07 & 0.50 & 0.24 & 10 \\
Mature Bullocks/oxen & 0.05 & 27.18 & 0.1 & 4 & 0.13 & 1.50 & 0.4 & 1.50 & 0.07 & 0.50 & 0.24 & 10 \\
Mature Breeding bulls & 0.05 & 27.18 & 0.1 & 4 & 0.13 & 1.50 & 0.4 & 1.50 & 0.07 & 0.50 & 0.24 & 10 \\
Young bulls/ males & 0.05 & 27.18 & 0.1 & 4 & 0.13 & 1.50 & 0.4 & 1.50 & 0.07 & 0.50 & 0.24 & 10
\end{tabular}

Volatile solid (VS) from manure production was estimated based on feed intake and digestibility. Both of them are the variables also used to develop the Tier 2 enteric $\mathrm{CH} 4$ emission factors. Volatile solids are the organic material in livestock manure and consist of both biodegradable and no biodegradable fractions. The value calculated in present study were the total VS (both degradable and no biodegradable fractions) as excreted by each animal sub-category. Gross 
energy (GE) intake data and its DE\% from enteric fermentation were used in the process of VS estimation. The VS content of manure was estimated as follows;

$$
\mathrm{VS}=\left[\mathrm{GE}\left\{1-\frac{\mathrm{DE} \%}{100}\right)+(\mathrm{UE} * \mathrm{GE})\right) *[(1-\mathrm{Ash}) / 18.45)
$$

Where;

VS = volatile solid excretion per day on a dry-organic matter basis, $\mathrm{kg}$ VS / day

$\mathrm{GE}=$ gross energy intake, $\mathrm{MJ} /$ day

$D E \%=$ digestibility of the feed in percent from enteric fermentation

$(\mathrm{UE} * \mathrm{GE})=$ urinary energy expressed as fraction of GE (IPCC default value of 0.04$)$. Because of no country-specific values available in Ethiopia.

Ash (the ash content of manure) = calculated as a fraction of the dry matter feed intake (default IPCC value of 0.08 for cattle). Because of no country-specific values available in Ethiopia.

The value of $\mathbf{1 8 . 4 5}=$ is conversion factor for dietary GE content per $\mathrm{kg}$ of dry matter (MJ/ kg).

\section{RESULTS AND DISCUSSIONS}

\section{Methane emission factor from enteric fermentation}

Estimates of enteric $\mathrm{CH} 4$ factor for 8 cattle sub-categories are presented in Tables 5 . Enteric $\mathrm{CH} 4 \mathrm{EFs}$ (emission factors) ranged from 11 to $66 \mathrm{~kg}$ per head per year depending on class of sub-category. The mean $\mathrm{CH} 4 \mathrm{EFs}$ from enteric fermentation per head per year was highest for mature draught oxen (66 kg) and followed by lactating cows (65 kg). These values were substantially higher than the corresponding value for Kenyan dairy females $>2$ years (34.1 kg) and males $>2$ years (37.4 kg). The $\mathrm{CH} 4$ factor of $56 \mathrm{~kg} / \mathrm{head} /$ year for growing females (1-2 years) and $63 \mathrm{~kg} / \mathrm{head} / \mathrm{year}$ for growing males (1-2 years) were higher than the corresponding value of $32.7 \mathrm{~kg}$ for females $1-2$ years and $34.5 \mathrm{~kg}$ for males 1-2 years reported in Kenya, while $\mathrm{CH} 4$ factor for calves $<1$ year was $(11 \mathrm{~kg} / \mathrm{head} /$ year) lower than the value $(18.1$ $\mathrm{kg} / \mathrm{head} /$ year reported in Kenya (Goopya et al., 2018). Although the live weight of females in present study is lower, the higher EFs for mature females in present study attributed to energy expenditure for traction (all animals except calves used for traction) while, energy expenditure for traction was calculated only for mature males in Kenya report. The live weight of female animals (176 kg for heifers and $255 \mathrm{~kg}$ for lactating cows) in present study is lower than the types of females (220 and 267) used in Kenyan cattle. The higher EFs for male animals in present study may be related to higher live weight. The live weight of male animals ( 265 for breeding bulls and $335 \mathrm{~kg}$ for draught oxen) in present study was higher than the types of male animals (180 and $249.2 \mathrm{~kg}$ ) in Kenyan cattle. Moreover, difference in methodology of estimating feed intake and EFs may result in different values. In present study, IPCC tier 2 methodology was used while in Kenya they driving energy expenditure from production parameters to estimate EFs. The EFs for lactating cows in present study was slightly higher than enteric $\mathrm{CH} 4 \mathrm{EF}$ of $62.19 \mathrm{~kg} /$ head/year for non-dairy cattle in South Africa (Moeletsi et al., 2017) and lower than the value of $90.4 \mathrm{~kg} / \mathrm{head} /$ year for beef cows reported in Canada (Kebreab et al., 2006). The difference may be related to breed difference, body weight and feed parameters differences.

The mean enteric $\mathrm{CH} 4 \mathrm{EFs}$ obtained for mature animals (lactating cows and mature breeding bulls) in present study were higher than the mean of $41 \mathrm{~kg}$ EF per head per year for mature females and $49 \mathrm{~kg} / \mathrm{head} / \mathrm{year}$ for mature males/Bullocks reported by IPCC tier 12006 (IPCC, 2006) for Africa region. These differences are attributed to difference in live weight. The mean live weight of animals in present study using tier 2 method $(255 \mathrm{~kg})$ was higher than the mean live weight used in tier 1 method for African cattle $(210 \mathrm{~kg})$. Moreover, average daily milk yield and average hours spent for traction were higher in present study using tier 2 method compared to the values used by tier 1 method (IPCC 2006), which resulted in high-energy intake and EFs.

\section{Table 5 - Enteric CH4 emission factor for indigenous dual-purpose cattle in Ethiopia}

\begin{tabular}{lccc} 
Sub-category & Live weight in kg & GE, MJ/head/day & $\begin{array}{c}\text { Tier } 2 \text { EF factor, } \\
\text { kg/head/year }\end{array}$ \\
\hline Mature females > 3 years (lactating) & 255 & 151 & 65 \\
dry cows & 255 & 123 & 49 \\
Heifers (2-3 years) & 176 & 127 & 37 \\
Growing females 1-2 years & 125 & 58 & 56 \\
Mature draught oxen & 335 & 154 & 66 \\
Mature breeding bulls & 265 & 136 & 58 \\
Growing males 1-2 years & 162 & 149 & 63 \\
Calves < 1 year & 57 & 52 & 11 \\
GE= gross energy; EF= emission factor; MJ= mega joule. & & &
\end{tabular}

Methane emission factor from manure management

Methane emission factor from manure management was estimated to be 5.06, 4.97, 4.87, 4.46, 4.33, 3.78, 2.86 and $1.71 \mathrm{~kg}$ head per year for mature draught oxen, lactating cows, growing males, mature males, growing females, dry 
cows, heifers and calves $<1$ year, respectively (Table 6). The higher values for mature draught oxen and lactating cows are attributed to higher volatile solid content of the manure as compared to other sub-categories. Manure management $\mathrm{CH} 4$ emission factor in present study is greater than manure management $\mathrm{CH} 4$ emission factor of $2.5 \mathrm{~kg}$ per head per year reported for Canadian beef cattle (Kebreab et al., 2006). The higher value for Ethiopian cattle breed compared with Canadian beef cattle is attributed to difference in manure management system/practice, difference in volatile solid content of manure/excreta and difference in digestibility of feed. The VS content of manure is the portion of the feed consumed by animals that is not digested and thus excreted as fecal material and this may be combined with urinary excretions, constitutes manure (Hristov et al., 2019). GHG emissions of cattle excreta vary by diet, breed and type of manure management practice used (Hristov et al., 2019). The lower digestibility of feed (50\%) in present study resulted in increased VS content of manure and hence $\mathrm{CH} 4$ emission from manure. In present study, due to lack of country specific Bo value, we used IPCC default values of 0.1 for Africa region (IPCC, 2006). CH4 emission in present study using tier 2 methodologies was higher compared to IPCC default manure management emission factor $(1 \mathrm{~kg} / \mathrm{head} / \mathrm{year})$ for other cattle (IPCC, 2006). The higher value for tier 2 is attributed to higher VS contents of manure. The estimated VS content of manure that was used to calculate manure management methane emissions in present study was on average 3.28 $\mathrm{kg} / \mathrm{head} /$ year which is higher than the default values of $1.5 \mathrm{~kg} / \mathrm{head} /$ year in IPCC (2006) tier 1 for Africa region. Difference in manure management system (MS) also contributed to the difference between tier 2 and tier 1 MMS CH4 emission factor. Tier 1 (solid (1\%), pasture (83\%), daily spread (5\%), burn for fuel $(6 \%)$ and other (4\%) but liquid and dry lot storage system was not accounted while in tier 2 both liquid and dry lot system were used in addition to pasture/rang drop, liquid system, solid system, daily spread and burn for fuel.

Table 6 - Manure management $\mathrm{CH} 4$ emission factor (kg/head/year)

\begin{tabular}{lcc} 
Sub categories & VS, content of manure, $\mathrm{Kg} / \mathrm{head} /$ day & CH4 emission factor, $\mathrm{kg} / \mathrm{head} / \mathrm{year}$ \\
\hline Lactating cows & 4.075 & 4.972 \\
Dry cows & 3.096 & 3.777 \\
Heifers (2-3 years) & 2.344 & 2.860 \\
growing Females (1-2 years) & 3.552 & 4.333 \\
Mature males/ draught oxen & 4.148 & 5.060 \\
Mature breeding bulls & 3.662 & 4.467 \\
growing males (1-2 years) & 3.999 & 4.879 \\
Calves < 1 years & 1.404 & 1.713 \\
Average & 3.28 & 4.008 \\
VS=volatile solid; CH4= methane. & & \\
\hline
\end{tabular}

\section{CONCLUSION}

In the present study, enteric fermentation and manure management $\mathrm{CH} 4$ emission factor were estimated using intergovernmental panel on climate change (IPCC), tier 2 methodologies from information collected through survey and literature reports. Enteric $\mathrm{CH} 4$ emission factor using tier 2 methodologies in present study ranged from 11 to $66 \mathrm{~kg}$ per head per year while manure management $\mathrm{CH} 4$ emission factor ranged from 1.71 to $5 \mathrm{~kg}$ per head per year. These values are higher than the IPCC (2006) tier 1 values for African region. However, present estimates are within a range of literature reports on cattle species in different countries using tier 2 methodologies. The present study is based on limited survey and published data, further research is required to improve emission factors using primary data on live weight, animal performance and feed characterization with recent and advanced technologies.

\section{DECLARATIONS}

\section{Corresponding author}

Email: kefalegetahn@gmail.com

\section{Authors' contribution}

Both authors contributed equally in the idea generation, proposal writing, data collection, data analysis, data interpretation, manuscript drafting (writing) and all the review processes.

\section{Conflict of interest}

The authors declared that no potential conflict of interest is reported regarding the subject matter of this manuscript.

\section{Acknowledgement}

Acknowledgment is granted for the experts who participated in the survey work. 


\section{REFERENCES}

Abera H, Abegaz S and Mekasha Y (2012). Genetic parameter estimates of pre-weaning weight of Horro (Zebu) and their crosses with Holstein Friesian and Jersey cattle breeds in Ethiopia. International Journal of Livestock Production, 2(6): 84-91. Link: https://academicjournals.org/article/article1379433709_Abera\%20et\%20al.pdf

Ayele S, Workalemahu A, Jabar, MA and Belachew, H (2003). Livestock Marketing in Ethiopia. A Review of Structure, Performance and Development Initiatives. Socio-economic and Policy Research Working Paper 52. International Livestock Research Institute (ILRI), Nairobi, http://www.fao.org/fileadmin/templates/agphome/images/iclsd/documents/wk2_c5_gerard.pdf

Berhanu Y, Olav L, Nurfeta A, Angassa A, and Aune JB (2019). Methane emissions from ruminant livestock in Ethiopia: promising forage species to reduce CH4 emissions. Agriculture, 9:130. DOI: https://doi.org/10.3390/agriculture9060130

CRGE (Ethiopia's Climate Resilience Green Economy) (2011). Green Economy Strategy, Federal Republic of Addis Ababa, Ethiopia. Link: https://www.undp.org/content/dam/ethiopia/docs/Ethiopia\%20CRGE.pdf.

CSA (Federal Democratic Republic of Ethiopia Central Statistics Authority) (2017). Agricultural Sample Survey II. Report on Livestock and Livestock Characteristics. Statistical Bulletin. Addis Ababa, Ethiopia. Link: https://searchworks.stanford.edu/view/6509594.

DAGRIS (Domestic Animal Genetic Resources Information System) (2007). (Edited by: JEO Rege, O Hanotte, Y Mamo, B Asrat and $T$ Dessie). International Livestock Research Institute, Addis Ababa, Ethiopia. Link: http://www.fao.org/3/i6686t/i6686t.pdf.

Demeke S, Neser FWC and Schoeman SJ (2003). Early growth performance of Bos Taurus x Bos indicus crosses in Ethiopia. Evaluation of different crossbreeding Models. Journal of Animal Breeding and Genetics, 120: 39-50. D0I: https://doi.org/10.1046/j.1439-0388.2003.00374.x

Demeke S, Neser FWC and Schoeman SJ (2004). Estimation of genetic parameters for Boran, Friesian, and crosses of Friesian and Jersey with Boran in the Tropical high lands of Ethiopia. Milk production traits and cow weight. Journal of Animal Breeding and Genetics, 121: 163-175. DOI: https://doi.org/10.1111/j.1439-0388.2004.00446.x

Epsten H (1971). The origin of the domestic Animals of Africa. Africana publishing corporation, New York, USA. Link: https://scholar.google.com/scholar?cluster $=17622104861051670325 \& \mathrm{hl}=e n \& a s \_s d t=2005 \&$ sciodt $=0,5$

Ermias E (2001). Field report on the Ogaden breed of cattle maintained at Alemaya University, Alemaya, Ethiopia. Link: https://cgspace.cgiar.org/handle/10568/70883

Goopya JP, Onyangoa AA, Dickhoefer U, Butterbach-Bahla K (2018). A new approach for improving emission factors for enteric methane emissions of cattle in smallholder systems of East Africa. Agricultural Systems, 161: 72-80. DOI: https://doi.org/10.1016/j.agsy.2017.12.004

Mekonnen G (1983). Preliminary Evaluation of Holstein Breeds and their Half breed for milk production. Ethiopian Journal of Agricultural Science, 5: 43-49. Link: http://agris.fao.org; Google Scholar

Haile-Mariam M. (1994).Genetic analysis of Boran, Friesian and crossbred cattle in Ethiopia. Ph.D. thesis. Swedish University of $\begin{array}{llllll}\text { Agricultural } & \text { Sciences. } & \text { Upsala, } & \text { Sweden. } & \text { pp. } & \text { 84-117. }\end{array}$ http://publication.eiar.gov.et:8080/xmlui/handle/123456789/1723

Haileselassie M, Redae G, Berhe G, Henry CJ, Nickerson MT, Tyler B, and Mulugeta A (2020). Why are animal source foods rarely consumed by 6-23 months old children in rural communities of Northern Ethiopia? A qualitative study. PLoS ONE, 15(1): e0225707. DOI: https://doi.org/10.1371/journal.pone.0225707

Hristov AN, Bannink A, Crompton LA, Huhtanen P, Kreuzer M, McGee M, Nozière P, Reynolds CK, Bayat AR, Yáñez-Ruiz DR, et al. (2019). Invited review: Nitrogen in ruminant nutrition: A review of measurement techniques. Journal of Dairy Science, 102(7): 5811-5852. DOI: https://doi.org/10.3168/jds.2018-15829

IPCC (Intergovernmental Panel for Climate Change) (2006). Guideline for National Green House Gas Inventory, Agriculture, forestry and other land use. Chapter 10 emissions from Livestock and manure management. Inventory of U.S. Greenhouse Gas Emissions and Sinks: 1990-2004. April 2006. USEPA \#430-R-06-002. Link: http://www.ipcc-nggip.iges.or.jp.pdf

Kebreab EK, Wagner-Riddle C and France F (2006). Methane and Nitrous Oxide emission from Canadian Animal Agriculture. Canadian Journal of Animal Science, 86: 135-158. Link: https://cdnsciencepub.com/doi/pdf/10.4141/A05-010

Kiwuwa GH, Trail JCM, Kurtu MY, Worku G, Anderson F and Durkin J (1983). Crossbred dairy cattle productivity in Arsi Region, Ethiopia. ILCA Research Report 11, International Livestock Centre for Africa, 1-29 pp. Link: https://core.ac.uk/download/pdf/132634989.pdf

Moeletsi ME, Tongwane MI and Tsybo M (2017). Enteric Methane Emissions Estimate for Livestock in South Africa for 19902014. Atmosphere, 8: 69 2-12. DOI: https://doi.org/10.3390/atmos8050069

Moges D and Baars R (1998). Long-term evaluation of milk production and reproductive performance of dairy cattle at Alemaya. pp 176-183 In: Proc. of $6^{\text {th }}$ Annual Conference of Ethiopian Society of Animal Production (ESAP), 14-15 May, 1998, Addis Ababa, Ethiopia. Link: http://hdl.handle.net/123456789/2455

Seyoum B, Zinash S and Dereje F (2007). Chemical Composition and Nutritive Values of Ethiopian Feeds. Research Report 73, EIAR, Addis Ababa, Ethiopia. Link: http://197.156.72.153:8080/xmlui/handle/123456789/2717

Shapiro BI, Gebru G, Desta S, Negassa A, Nigussie K, Aboset G and Mechale H (2017). Livestock Sector Analysis: A 15-year livestock sector strategy. ILRI project report. Nairobi, Kenya: ILRI. Link: https://www.ilri.org.publications.

Sheehy T, Carey E, Sharma S and Biadgilign S (2019). Trends in energy and nutrient supply in Ethiopia: a perspective from FAO food balance sheets. Nutrition Journal, 18: 46. Dol: https://doi.org/10.1186/s12937-019-0471-1

Trail, JCM and Gregory, KE (1981). Characterization of Boran and Sahiwal breeds of cattle for economic characters. Journal of Animal Science, 52: 1286-1293. DOI: https://doi.org/10.2527/jas1981.5261286x. 